\title{
An appraisal of the virulence factors associated with streptococcal endocarditis
}

\author{
J. E. MANNING*, E. B. H. HUME, N. HUNTER and K. W. KNOX \\ Institute of Dental Research, United Dental Hospital, 2 Chalmers Street, Sydney NSW 2010, Australia
}

\begin{abstract}
Summary. Platelet aggregation is believed to be a virulence factor in infective endocarditis. Other factors may be adhesion to components of thrombotic vegetations, particularly platelets, fibronectin and fibrinogen. Two strains from the Streptococcus sanguis group (SSG) were chosen for comparative study on the basis that one aggregated both human and rat platelets and the other lacked this capacity. Both strains caused endocarditis in the rat model but the aggregating strain was found in higher numbers in the excised vegetations. The nonaggregating strain was unable to bind to human or rat platelets but could bind insoluble fibronectin, insoluble fibrinogen and platelet-fibrin clots from both sources, albeit to a lesser extent than the aggregating strain. These results suggest that whereas adhesion to, and aggregation of, platelets are not essential events in the initiation of the pathogenesis of experimental endocarditis, they may be factors contributing to virulence.
\end{abstract}

\section{Introduction}

Viridans streptococci form part of the normal oral flora and their entry to the blood stream as a result of dental procedures, for example, may lead to infective endocarditis; this involves the colonisation of plateletfibrin vegetations on the endothelial surface of the heart. One possible factor in the pathogenesis of infective endocarditis is direct aggregation of platelets by bacteria, ${ }^{1-4}$ but it is also possible that bacteria may colonise the damaged valvular surface by their adherence to platelets and extracellular matrix proteins such as fibronectin and fibrinogen ${ }^{5,6}$ Such conclusions have been based generally on assays in vitro with human components and on to a limited number of assays in vivo in animals. There has been no comprehensive analysis hitherto of the relationship between binding and platelet-aggregating properties in vitro for the human and animal system and the capacity to cause endocarditis in the animal model.

Members of the Streptococcus sanguis group (SSG) are the oral streptococci most frequently isolated from infective endocarditis. ${ }^{78}$ Previous work (Manning et al., unpublished observations) showed that SSG strain FSS2 aggregates both human and rat platelets to the same final percentage but with different lag phases. In the same study, 25 SSG strains were compared for their ability to aggregate human and rat platelets. A lag phase of $>3 \mathrm{~min}$ was found for $92 \%$ of strains

Received 14 July 1993; accepted 15 July 1993.

* Present address: Department of Physiological Sciences, The Medical School, University of Newcastle upon Tyne, Newcastle upon Tyne NE2 $4 \mathrm{HH}$. with human platelets whereas all strains had a lag phase of $<3 \mathrm{~min}$ with rat platelets. Strain FSS2, isolated from a patient with endocarditis, is, therefore, a typical SSG strain in its ability to aggregate both human and rat platelets. Strain L50, a dental plaque strain that does not aggregate human or rabbit platelets, ${ }^{9}$ has now been shown to be unable to aggregate rat platelets. Thus, the aim of this study was to compare the two SSG strains for other possible virulence factors in tests with both human and rat products, and to relate these properties to the capacity of the strains to cause endocarditis in the rat.

\section{Materials and methods}

\section{Bacterial strains and culture conditions}

The two strains studied were FSS2, isolated from a patient with endocarditis at Freeman Hospital, Newcastle upon Tyne, and L50, a dental plaque strain kindly provided by Dr M. Herzberg, University of Minnesota, Minneapolis, USA. Both strains were stored in glycerol $30 \% \mathrm{v} / \mathrm{v}$ at $-70^{\circ} \mathrm{C}$. Purity was checked by plating out on Columbia Agar (Oxoid) supplemented with horse blood (Amadeus) $5 \% \mathrm{v} / \mathrm{v}$. Organisms were grown in Brain-Heart Infusion Broth (Oxoid) supplemented with yeast extract (Oxoid) $0.3 \%$ $\mathrm{w} / \mathrm{v}$ at $37^{\circ} \mathrm{C}$ for $18 \mathrm{~h}$ in an anaerobic jar. Where radiolabelling was necessary ${ }^{3} \mathrm{H}$-thymidine (Dupont) was added to the medium at $74 \mathrm{kBq} / \mathrm{ml}$. For all assays, the cultures were washed three times in phosphatebuffered saline (PBS), $\mathrm{pH} 7 \cdot 3,(\mathrm{~g} / \mathrm{L}-\mathrm{NaCl} 8.0 ; \mathrm{KCl}$ $\left.0 \cdot 2 ; \mathrm{Na}_{2} \mathrm{HPO}_{4} \cdot 12 \mathrm{H}_{2} \mathrm{O} 2 \cdot 9 ; \mathrm{KH}_{2} \mathrm{PO}_{4} 0 \cdot 2\right)$ and routinely resuspended to an $\mathrm{OD}_{660}$ of $1 \cdot 00 \pm 0 \cdot 02$. 
Table I. Results of in-vitro adhesion assays with human components

\begin{tabular}{|c|c|c|c|c|}
\hline \multirow{3}{*}{ Adhesion assay with } & \multicolumn{4}{|c|}{$\begin{array}{c}\text { Mean (SD) } \\
\text { adherent cells }\left(10^{6}\right)\end{array}$} \\
\hline & \multicolumn{2}{|c|}{ Strain FSS2 } & \multicolumn{2}{|c|}{ Strain L50 } \\
\hline & $\begin{array}{l}1 \times 10^{8} \\
\text { cells } / \mathrm{ml}\end{array}$ & $\begin{array}{l}1 \times 10^{9} \\
\text { cells } / \mathrm{ml}\end{array}$ & $\begin{array}{c}1 \times 10^{8} \\
\text { cells } / \mathrm{ml}\end{array}$ & $\begin{array}{l}1 \times 10^{9} \\
\text { cells } / \mathrm{ml}\end{array}$ \\
\hline Platelets & $44 \cdot 9(5 \cdot 7)$ & $192.4(10.0)$ & $-8.9(2.0)$ & $-1 \cdot 1(16 \cdot 0)$ \\
\hline Insoluble fibronectin & $7 \cdot 6(0 \cdot 7)$ & $50 \cdot 4(4 \cdot 0)$ & $4 \cdot 1(1 \cdot 1)$ & $40.9(20.2)$ \\
\hline Insoluble fibrinogen & $7.0(1.0)$ & $41 \cdot 4(7 \cdot 1)$ & $3.3(1.9)$ & $24.2(1.9)$ \\
\hline Platelet-fibrin clots & $3 \cdot 3(0 \cdot 4)$ & $22 \cdot 1(6 \cdot 2)$ & $2.7(1.4)$ & $7 \cdot 9(4 \cdot 8)$ \\
\hline
\end{tabular}

\section{Interaction with platelets}

Preparation of standardised platelet suspensions. Human blood, containing $0 \cdot 1 \mathrm{M}$ tri-sodium citrate $(9: 1 \mathrm{v}: \mathrm{v})$ as an anticoagulant, was supplied by the Red Cross Blood Bank, Sydney, Australia, from normal donors who were known to be free of infection and had taken no medication for at least 2 weeks before donation. A supernate of platelet-rich plasma (PRP) was prepared by centrifugation of the blood from at least two donors at $100 \mathrm{~g}$ for $10 \mathrm{~min}$ at $20^{\circ} \mathrm{C}$, and platelet-poor plasma (PPP) was prepared by further centrifugation of the remainder of the blood at $2350 \mathrm{~g}$ for $10 \mathrm{~min}$. PRP for the aggregation experiments was adjusted to an $\mathrm{OD}_{660}$ of 0.5 with PPP. Rat blood was collected, under anaesthesia, from the heart into a syringe containing $0 \cdot 1 \mathrm{M}$ tri-sodium citrate $(9: 1$ $\mathrm{v}: \mathrm{v})$ and PRP and PPP were prepared by the same method as for human blood.

Platelet aggregation assay. PRP $(250 \mu \mathrm{l})$ was equilibrated to $37^{\circ} \mathrm{C}$ in a recording aggregometer (model 430 Chronolog Corp., Haverton, PA, USA) and adenosine diphosphate (ADP) was added to a final concentration of 5-20 $\mu \mathrm{M}$, as a positive control for the viability of the platelets; $25 \mu \mathrm{l}$ of bacterial suspension was added to subsequent aliquots of PRP to give a final bacteria:platelet ratio of $c .1: 1$. Preliminary studies showed that this ratio produced optimal aggregation. The recorded traces were measured over a period of $25 \mathrm{~min}$ for the lag phase, the period from the addition of the bacteria to the stirring PRP until a deviation in baseline occurred, and the final percentage aggregation. Assays were performed on at least three different occasions.

Platelet adhesion assay. All microtitration plates and centrifuge tubes were pre-coated with PBS containing bovine serum albumin $1 \%$ and Tween 20 $0.05 \%$ (PBS-BSA). An iso-osmotic solution of Percoll (Pharmacia) $90 \% \mathrm{v} / \mathrm{v}$ in PBS was diluted with PBS to determine the concentration required for each strain to be deposited on the bottom of the tube after centrifugation at $5000 \mathrm{~g}$ for $20 \mathrm{~min}$. The respective concentrations for strains FSS2 and L 50 were $50 \%$ and $25 \%$. PRP was washed three times in PBS containing $5 \mathrm{~mm}$ EDTA to produce platelet ghosts and resuspended to an $\mathrm{OD}_{660}$ of 0.5 . Platelet ghosts $(100 \mu \mathrm{l})$ and radio- labelled bacterial suspension $\left(100 \mu \mathrm{l} ; 1 \times 10^{8}\right.$ cells $/ \mathrm{ml}$ and $1 \times 10^{9}$ cells $/ \mathrm{ml}$, respectively) were added to wells of a microtitration plate (Nunc, Denmark) and shaken for $20 \mathrm{~min}$ at room temperature. The suspension from each well and a PBS wash $(100 \mu \mathrm{l})$ were carefully layered on to the pre-determined concentration of Percoll and centrifuged at $5000 \mathrm{~g}$ for $20 \mathrm{~min}$. Platelets with adherent bacteria remained at the top of the centrifuge tube whereas unbound bacteria were centrifuged to the bottom. Controls were bacteria incubated with PBS only. Samples $(200 \mu \mathrm{l})$ were taken from the top and the bottom of the Percoll and counted in a scintillation counter to determine the numbers of bound bacteria. Assays were performed in triplicate with two separate batches of cells.

Adhesion to platelet-fibrin clots. PRP $(250 \mu \mathrm{l})$ and $0.3 \mathrm{M} \mathrm{CaCl}_{2}(100 \mu \mathrm{l})$ were added to wells of a tissueculture plate (24-well plate; well size $16 \mathrm{~mm} \times 16 \mathrm{~mm}$; Nunc) and incubated at $37^{\circ} \mathrm{C}$ for $30 \mathrm{~min}$ to form a clot. A radiolabelled bacterial inoculum $\left(1 \times 10^{8}\right.$ cells $/ \mathrm{ml}$ and $1 \times 10^{9}$ cells $\left./ \mathrm{ml}\right)$ was added to each well $(300 \mu \mathrm{l})$ and shaken at room temperature for $1 \mathrm{~h}$. Control clots were shaken with PBS only. The supernate was removed and the clot surface was washed several times in PBS to remove non-adherent bacteria, dissolved with streptokinase $(0.3 \mathrm{U} / \mathrm{ml}, 0.5 \mathrm{ml}$; Boehringer Mannheim, Germany) and transferred to scintillation vials. Bacterial suspension $(300 \mu \mathrm{l})$ was added to the dissolved control clots to determine the amount of radioactivity associated with each cell; the number of bound bacteria in the samples could then be calculated. Assays were performed in duplicate with two different batches of cells.

\section{Binding to insoluble fibronectin and fibrinogen}

Rat fibronectin was prepared by the method of Vuento and Vaheri. ${ }^{10}$ Rat fibrinogen was then prepared from the fibronectin-deficient plasma by precipitation with ammonium sulphate $25 \%$ followed by chromatography on a Sepharose CL-6B column $(2.5 \times 70 \mathrm{~cm})$ with PBS as the equilibration buffer. The proteins were judged to be pure by polyacrylamide gel electrophoresis. Human fibronectin and fibrinogen were purchased from Sigma. Each protein $(200 \mu \mathrm{l}$; $5 \mu \mathrm{g} / \mathrm{ml}$ in PBS) was pipetted into wells of a micro- 
titration plate (Nunc) and left overnight at $4^{\circ} \mathrm{C}$. Control wells contained PBS only. Unbound protein was removed by washing in PBS-BSA before the addition of a radiolabelled bacterial suspension $\left(100 \mu \mathrm{l} ; 1 \times 10^{8}\right.$ cells $/ \mathrm{ml}$ and $1 \times 10^{9}$ cells $\left./ \mathrm{ml}\right)$. Microtitration plates were shaken for $30 \mathrm{~min}$ at room temperature and washed several times in PBS. Adherent bacteria were solubilised by the addition of sodium dodecyl sulphate (SDS) $2.5 \%$ in $0.2 \mathrm{M} \mathrm{NaOH}$ $(100 \mu \mathrm{l})$ to the well for $30 \mathrm{~min}$ followed by neutralisation with $0.05 \mathrm{M}$ acetic acid $(400 \mu \mathrm{l})$. The contents of each well were then counted on a scintillation counter to determine the number of bound organisms. Assays were performed in triplicate on two different batches of cells.

\section{In-vivo endocarditis model}

Bacterial endocarditis was established in female Sprague-Dawley rats weighing $c .200 \mathrm{~g}$ by the technique of Santoro and Levison. ${ }^{11} \mathrm{~A}$ polyethylene catheter $(0.5 \mathrm{~mm}$ internal diameter; Dural Plastics, NSW, Australia) was inserted across the aortic valve via the right carotid artery, sealed and left in place throughout the experiment. The infecting strain $\left(5 \times 10^{7} \mathrm{cfu}\right.$ in $0.5 \mathrm{ml}$ PBS$)$ was injected through the tail vein $48 \mathrm{~h}$ after catheterisation. Control rats were shamoperated with placement and withdrawal of the catheter and given strain FSS2 or catheterised and given PBS. At post-mortem examination the abdominal organs were inspected for evidence of metastatic disease and the hearts for correct placement of the catheter. Following removal, catheters were placed in brain heart infusion broth $(10 \mathrm{ml})$ for qualitative culture. All aortic vegetations were excised aseptically, weighed and homogenised in $5 \mathrm{ml}$ of sterile PBS $96 \mathrm{~h}$ after bacterial injection. Colony counts were performed on blood agar plates and incubated at $37^{\circ} \mathrm{C}$ for $18 \mathrm{~h}$. Bacterial titres were recorded as total cfu, and $\mathrm{cfu} / \mathrm{mg}$ of vegetation. All strains from resected vegetations were identified by colonial morphology, haemolysis on blood agar plates, Gram's stain and capacity to aggregate platelets. Differences in bacterial titres within vegetations among groups were assessed by the non-parametric Mann-Whitney U test.

\section{Results}

\section{In-vitro assays}

Strain FSS2 aggregated both human and rat platelets to a final value of $85-90 \%$; the lag phase was $8 \mathrm{~min}$ for human platelets and $<0.5 \mathrm{~min}$ for rat platelets. Strain L50 was unable to aggregate either human or rat platelets.

Strains FSS2 and L50 at concentrations of $1 \times 10^{8}$ cells $/ \mathrm{ml}$ and $1 \times 10^{9}$ cells $/ \mathrm{ml}$ were compared for their capacity to bind platelets, insoluble fibronectin, insoluble fibrinogen and platelet-fibrin clots. Table I gives the results for human components and table II for rat components.
The number of adherent bacteria at the 10-fold higher cell concentration was only increased by 10 fold in one case, the binding of insoluble human fibronectin by strain L50; binding may have been approaching saturation level at the higher cell concentration. The values at the higher concentration highlight the differences between the strains.

With human components strain FSS2 was more active than strain L50 in all assays. The most obvious difference, up to 200 -fold, was in platelet adhesion but there were two-fold and three-fold differences, respectively, in binding to insoluble fibrinogen and platelet-fibrin clots; the difference for insoluble fibronectin was marginal. The same general trend was seen as with rat components; the difference for platelet adhesion was 12-fold and the respective differences for binding to insoluble fibronectin, insoluble fibrinogen and platelet-fibrin clots were three-fold, seven-fold and two-fold respectively.

Strain FSS2 adhered better to human platelets than to rat platelets by a factor of 16 but the results were similar in all other assays. Strain L50 was unable to adhere to either human or rat platelets but bound three times more effectively to insoluble human fibronectin and fibrinogen then to rat components. Adhesion to platelet-fibrin clots was the same for both strains.

\section{Animal model of endocarditis}

Twenty-six rats were used in the production of experimental endocarditis; eight were given strain FSS2 (two rats from this group died before harvest), seven strain L50, three PBS and eight were shamoperated.

The catheters from the PBS controls showed no visible growth of organisms on culture, whereas there was growth on the catheters of infected animals. All vegetations with organisms yielded pure cultures and the organisms were the same as those used to infect the animal. No bacteria were detectable in any of the animals given PBS or in five of eight shamoperated animals. The other three sham-operated animals had $750,1 \times 10^{3}$ and $3 \times 10^{4}$ total cfu respectively.

The distribution of total $\log _{10}$ cfu recovered from the vegetations of each rat inoculated with strains FSS2 and L50 is shown in the figure. The values for strain FSS2, with a range of 5.26-11.23 and a median of 9.26, were significantly higher $(p=0.035)$ than for strain L50, for which the range was $0-8 \cdot 20$ with a median of 5.32. The distribution of $\log _{10} \mathrm{cfu} / \mathrm{mg}$ of tissue for both strains showed a similar difference. In four of six animals inoculated with strain FSS2 and two of seven animals inoculated with strain $\mathrm{L} 50$, the total recovered cfu exceeded the number injected.

The pathological condition at necropsy of each animal related to the treatment of the animal. Shamoperated, non-cannulated rats were generally healthy and all organs were normal. All cannulated rats showed some degree of congestion in the lungs and 
Table II. Results of in-vitro adhesion assays using rat components

\begin{tabular}{|c|c|c|c|c|}
\hline \multirow{3}{*}{ Adhesion assay with } & \multicolumn{4}{|c|}{$\begin{array}{c}\text { Mean (SD) } \\
\text { adherent cells }\left(10^{6}\right)\end{array}$} \\
\hline & \multicolumn{2}{|c|}{ Strain FSS2 } & \multicolumn{2}{|c|}{ Strain L50 } \\
\hline & $\begin{array}{l}1 \times 10^{8} \\
\text { cells } / \mathrm{ml}\end{array}$ & $\begin{array}{l}1 \times 10^{9} \\
\text { cells } / \mathrm{ml}\end{array}$ & $\begin{array}{c}1 \times 10^{8} \\
\text { cells } / \mathrm{ml}\end{array}$ & $\begin{array}{l}1 \times 10^{9} \\
\text { cells } / \mathrm{ml}\end{array}$ \\
\hline Platelets & $1.7(2 \cdot 2)$ & $12 \cdot 1(9 \cdot 0)$ & $-1.9(1.5)$ & $-11.7(17.9)$ \\
\hline Insoluble fibronectin & $6.5(0.7)$ & $44 \cdot 9(5 \cdot 2)$ & $5 \cdot 9(2 \cdot 7)$ & $13 \cdot 7(4 \cdot 4)$ \\
\hline Insoluble fibrinogen & $10 \cdot 6(1 \cdot 2)$ & $54 \cdot 2(7 \cdot 1)$ & $3 \cdot 1(2 \cdot 8)$ & $7 \cdot 5(1 \cdot 1)$ \\
\hline Platelet-fibrin clots & $5 \cdot 7(0.9)$ & $13 \cdot 2(1 \cdot 6)$ & $3.5(0.9)$ & $7 \cdot 2(2 \cdot 7)$ \\
\hline
\end{tabular}

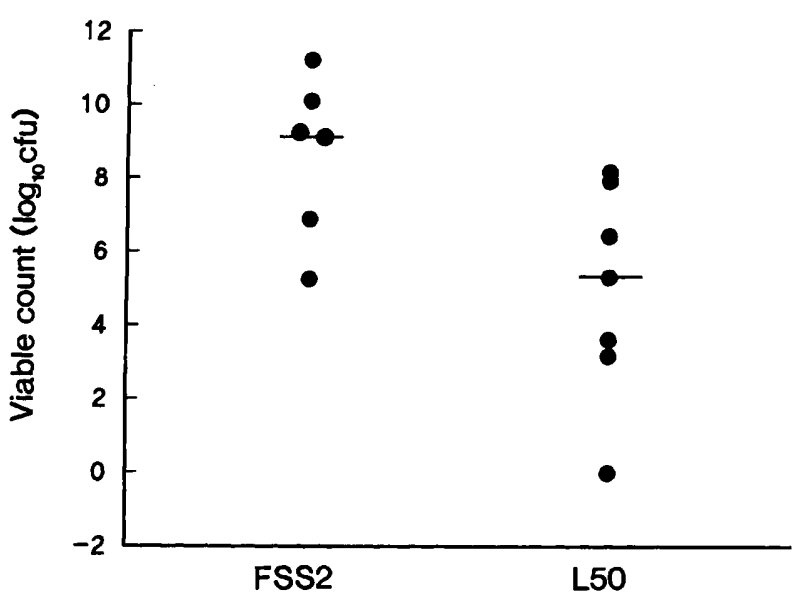

Figure. Distribution of the total $\log _{10} \mathrm{cfu}$ of bacteria cultured from each vegetation of catheterised rats infected with strains FSS2 and L50. The bars represent the median value for each strain.

those with large numbers of bacteria within the vegetations had renal abscesses.

\section{Discussion}

The ability to aggregate platelets has been associated with the capacity to cause endocarditis. ${ }^{\mathbf{1 - 4}}$ Strain FSS2, an endocarditis isolate, aggregates human and rat platelets (Manning et al., unpublished observations). The present studies in conjunction with previous work ${ }^{9}$ show that strain L50 is unable to aggregate platelets from either source within the defined period.

The adhesion of bacteria to platelets in endocardial vegetations may lead to further deposition of platelets and the development of platelet-fibrin matrices, followed by enlargement of the vegetations. The adhesion of bacteria to platelets has been suggested as a prerequisite for platelet aggregation. ${ }^{2}$ Strain FSS2 adheres to both human and rat platelets but in much higher numbers to human platelets. Results obtained for Staphylococcus aureus ${ }^{12}$ showed that the ability of staphylococcal cells to adhere to platelets depended upon the availability of platelet-receptor sites for the organism rather than on the affinity of the organism for the platelet surface. If SSG strains behave similarly, these results would suggest that the lesser binding of strain FSS2 to rat platelets may be due to fewer platelet receptors, although the number must still be sufficient to trigger aggregation. Strain L50 adheres very poorly to human or rat platelets and, apparently, in insufficient numbers to cause aggregation.

Both strains bind to insoluble human and rat fibronectin; strain FSS2 is marginally superior in regard to human fibronectin and three times better for rat fibronectin. There is now an awareness of the role of fibronectin in the adherence of circulating organisms to damaged heart valves. ${ }^{6}$ Fibronectin is present in increased amounts at the sites of endothelial injury and repair, on the surface of thrombotic lesions, on the surface of platelets and within platelet $\alpha$-granules. Fibronectin exists in soluble form in plasma and can change conformation when bound in an insoluble form to other molecules and substrates such as gelatin, collagen and plastic. S. sanguis has also been shown to bind to insoluble fibronectin even in the presence of large amounts of soluble fibronectin ${ }^{13}$ suggesting that adherence to immobilised fibronectin may be more important in streptococcal endocarditis. Studies in vitro have shown that organisms bind better to artificial thrombi formed in the presence of fibronectin than thrombi formed from fibronectin-deficient plasma $^{14}$ and studies with animal models have shown that the adhesion of $S$. sanguis to insoluble fibronectin ${ }^{15}$ in vitro correlated with the ability to produce endocarditis in rats. This evidence indicates that binding to insoluble fibronectin plays a role in endocarditis.

Little information is available on the role of fibrinogen in infective endocarditis. Fibrinogen is present in a soluble and an insoluble form and may act in a similar way to fibronectin. Fibrinogen, as fibrin, is also one of the major components of vegetations. Both strains have been shown in this study to bind insoluble fibrinogen, strain L50 less effectively.

The assay of adhesion to platelet-fibrin clots simulates the adherence of bacteria to vegetations and may involve the same interactions as adhesion to soluble fibronectin and fibrinogen, since platelet-fibrin clots have been shown to contain fibronectin and fibrinogen. ${ }^{6}$

It is not known whether strain L50 can cause endocarditis in man, but the comparison in vitro of the characteristics of the two strains and their potential to 
cause endocarditis in the rat leads to some conclusions. Infection with strain FSS2 produced significantly larger vegetations and also produced embolic spread manifested principally as multifocal renal abscess. However, the finding that strain L50 could cause endocarditis suggests that platelet aggregation is not an initiating factor in the pathogenesis of endocarditis, although it may still be a virulence factor. These results are in agreement with recent results obtained by Herzberg et al.$^{9}$ with the rabbit model. The difference in the capacity to aggregate platelets is reflected in

\section{References}

1. Clawson CC, White JG. Platelet interaction with bacteria. I. Reaction phases and effects of inhibitors. Am $J$ Pathol 1971 ; 65: 367-380.

2. Herzberg MC, Brintzenhofe KL, Clawson CC. Aggregation of human platelets and adhesion of Streptococcus sanguis. Infect Immun 1983; 39: 1457-1469.

3. Sullam PM, Valone FH, Mills J. Mechanisms of platelet aggregation by viridans group streptococci. Infect Immun 1987; 55: 1743-1750.

4. Douglas CWI, Brown PR, Preston FE. Platelet aggregation by oral streptococci. FEMS Microbiol Lett 1990; 72: 63-68.

5. Scheld WM. Pathogenesis and pathophysiology of infective endocarditis. In: Sande MA, Kaye D, Root RK (eds) Endocarditis. New York, Churchill Livingstone. 1984: $1-32$

6. Hamill R. Role of fibronectin in infective endocarditis. Rev Infect Dis 1987; 9 Suppl 4: S360-S371.

7. Knox KW, Hunter $\mathrm{N}$. The role of oral bacteria in the pathogenesis of infective endocarditis. Aust Dent $J 1991$; 36: 286-292.

8. King K, Harkness JL. Infective endocarditis in the 1980s. Part 1. Aetiology and diagnosis. Med J Aust 1986; 144: 536-540. similar differences in adhesion to platelets. Both strains bind insoluble fibronectin and insoluble fibrinogen and adhere to platelet-fibrin clots; the results reflect the differences in this potential to cause endocarditis. The extent of the reaction of a strain with these mammalian tissue components may be important factors in the pathogenesis of endocarditis.

This work was supported by the National Health and Medical Research Council of Australia and the Dental Board of New South Wales, Australia. Thanks are also due to P. Williams for his help with the animal studies.

9. Herzberg MC, MacFarlane GD, Gong $\mathrm{K}$ et al. The platelet interactivity phenotype of Streptococcus sanguis influences the course of experimental endocarditis. Infect Immun 1992; 60: $4809-4818$.

10. Vuento M, Vaheri A. Purification of fibronectin from human plasma by affinity chromatography under non-denaturing conditions. Biochem J 1979; 183 : 331-337.

11. Santoro J, Levinson ME. Rat model of experimental endocarditis. Infect Immun 1978; 19: 915-918.

12. Yeaman MR, Norman DC, Bayer AS. Staphylococcus aureus susceptibility to thrombin-induced platelet microbicidal protein is independent of platelet adherence and aggregation in vitro. Infect Immun 1992; 60: 2368-2374.

13. Lowrance JH, Hasty DL, Simpson WA. Adherence of Streptococcus sanguis to conformationally specific determinants in fibronectin. Infect Immun 1988; 56: 2279-2285.

14. Toy PTCY, Lai L-W, Drake TA, Sande MA. Effect of fibronectin on adherence of Staphylococcus aureus to fibrin thrombi in vitro. Infect Immun 985: 48: 83-86.

15. Baddour LM, Lowrance C, Albus A, Lowrance JH, Anderson SK, Lee JC. Staphylococcus aureus microcapsule expression attenuates bacterial virulence in a rat model of endocarditis. $J$ Infect Dis 1992; 165: 749-753. 